\title{
Effects of Food Diet Preparation Techniques on Radionuclide Intake and Its Implications for Individual Ingestion Effective Dose in Abeokuta, Southwestern Nigeria
}

\author{
Nnamdi Norbert Jibiri*, Tolulope Hadrat Abiodun \\ Radiation and Health Physics Research Laboratory, Department of Physics, University of Ibadan, Ibadan, Nigeria \\ Email: jibirinn@yahoo.com, "nnamdi.jibiri@mail.ui.edu.ng
}

Received February 3, 2012; revised March 29, 2012; accepted April 15, 2012

\begin{abstract}
The radioactivity measurements in food crops and their diet derivatives and farm soil samples from Abeokuta, one of the elevated background radiation areas in Nigeria have been carried out in order to determine the concentration levels of natural radionuclides $\left({ }^{40} \mathrm{~K},{ }^{226} \mathrm{Ra}\right.$ and $\left.{ }^{232} \mathrm{Th}\right)$. The activity concentrations of the natural radionuclides in the samples were determined via gamma-ray spectrometry using a $76 \mathrm{~mm} \times 76 \mathrm{~mm} \mathrm{NaI}(\mathrm{Tl})$ detector. Different common food crops representing the major sources of dietary requirements to the local population were collected for the measurements. The collected food crops were prepared into their different derivable composite diets using preparation techniques locale to the population. Using available food consumption data and the activity concentrations of the radionuclides, the ingestion effective doses were evaluated for the food crops and diet types per preparation techniques. For the tuberous food crop samples, the annual ingestion effective doses in the raw and different composite diets were $0.02-0.04 \mu \mathrm{Sv}$ and cumulatively $0.04-0.05 \mu \mathrm{Sv}$ while in the non-tuberous crops the doses were $0.44-0.70 \mu \mathrm{Sv}$ and cumulatively greater than $1 \mu \mathrm{Sv}$ respectively. Results of the study indicate that method of diet preparation is seen to play a major role in population ingestion dose reduction especially for tuberous crops than in non-tuberous crops. The study also showed that more ingestion dose could be incurred in diets prepared by roasting techniques. The result of the study will serve as a useful radiometric data for future epidemiological studies in the area and for food safety regulations and policy implementations in the country.
\end{abstract}

Keywords: Natural Radionuclides; Radionuclide Intake; Gamma Ray Spectroscopy; Food Crops; Radiation Effective Ingestion Dose; Diet Preparation Techniques

\section{Introduction}

Natural radioactive elements are transferred and recycled through natural processes and between the various environmental compartments by entering into ecosystems and human food chains. The level of terrestrial radiation varies from a geographical location to another depending upon the variation of radionuclide concentration in soil which largely depend on the local geology $[1,2]$. Foods may be contaminated to some extent as a result of deposition of radionuclides on food crops or on pasture. However, radioactive contamination of the environment may result in the increased radiation exposure of human beings due to ingestion of radionuclides in food. In the chain of transfer processes which leads from the deposition of radionuclides onto soils and plant surfaces to their presence in the diet, food processing and the various methods of

"Corresponding author. food preparation are the last processes which can affect the radionuclide content of foodstuffs. Man's ingestion of radioactive materials may also result from drinking contaminated water in the environment.

Baseline studies of terrestrial outdoor gamma dose rate levels in Nigeria had shown that the areas under investigation exhibited high concentrations of natural radionuclides [1,3]. Also recently an annual effective dose rate of $1.64 \mathrm{mSv}$ due to environmental radiation has been reported for the city [4]. Metal pollution in shallow well water samples in the neighboring town to the study areas has been reported [5], radioactivity in borehole water in neighboring state [6] and in part of Ogun State [7]. It is therefore envisaged that radionuclide concentrations may be elevated in the different food crops and the diets derivable from them. For broad assessment of dose estimate, knowledge of the radiological impact on the effect of 
doses via ingestion in food and water chain as well as the effects of various preparation techniques on radionuclide content of food is therefore required, since the resulting dose from the persistence of a radionuclide in the body is a function of its radiological and biological half lives. Moreover, the carcinogenic nature and long half lives of many radionuclides make them a potential threat to human health. The objective of this work is to investigate the natural radioactivity levels $\left({ }^{226} \mathrm{Ra},{ }^{40} \mathrm{~K}\right.$ and $\left.{ }^{232} \mathrm{Th}\right)$ in some selected major food crops and evaluate the effects of varying methods of diet preparation techniques on the radionuclide contents of the food crops and the implication on population radiation ingestion dose.

\section{Materials and Methods}

\subsection{Food Sample Collection and Preparation}

Food crops and the soil in which they were grown were collected from some selected farmlands at Abata, Fami, Obakan logun, and Ita osu villages, located respectively in Odeda and Obafemi Owode local government Area of Ogun state (Figure 1). Food samples of white yam (Discorea specie), cassava (Manihot utilisima), Plantain (Plantago specie) and maize (Zea mays), were collected directly from farmlands in the villages to ensure they were site specific samples. Different samples of the same food crops were collected from three different farms across the area. Substantial quantity of food samples enough for the analysis was collected. Soil samples were also collected from the same location for analysis. All the food crop samples collected for analysis were native to these areas and represent the common food crop types and choice from where over $85 \%$ of daily food/diets needs and requirements of the population are derived. The food samples were washed and prepared fresh shortly after collection into different diets according to the major dietary preferences of the people in the locality, using varying techniques of food preparation. The source of water used for cooking and washing was from the water supply sources in the villages; such as hand dug well, bore hole etc. However, before the preparation of the samples, the non edible parts were discarded such as the peel of yam tuber, cassava as well as the infested parts in some of the food crops. To investigate the possible removal of radionuclide during diet preparation, part of the food samples were prepared using typical local practices, such as the making of yam into boiled and, roasted yam, and yam flour, cassava was made into lafun (Cassava flour), Cooked cassava (Amala) Flour and Fried Cassava paste-garri, plantain was prepared roasted and boiled, maize into boiled and roasted maize (Table 1). To ensure that the diet preparation represent true local

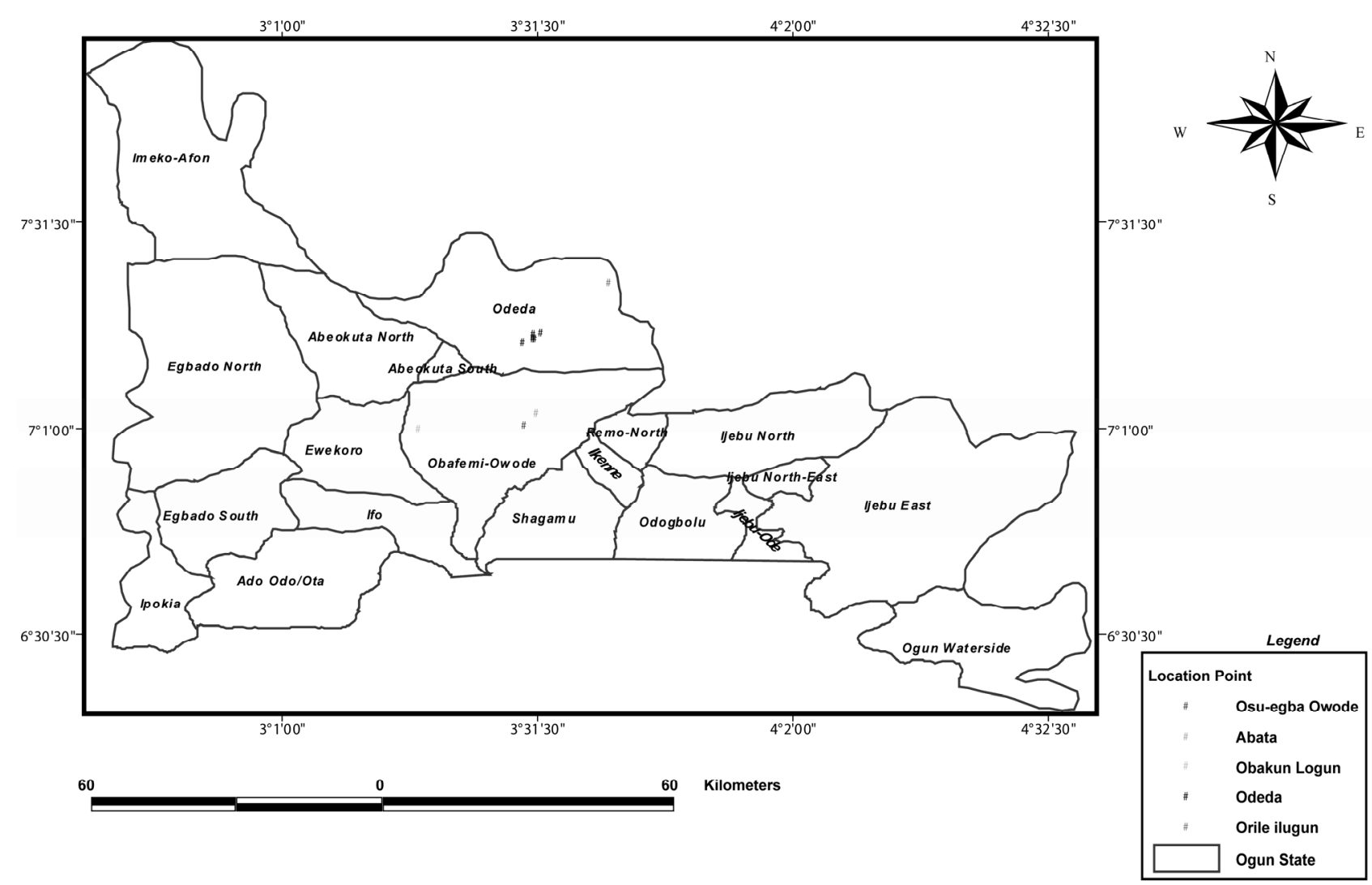

Figure 1. The map of Ogun State Nigeria showing the sample locations. 
Table 1. Common food crops, their local diet derivatives and preparation techniques.

\begin{tabular}{|c|c|c|}
\hline Crops & Diet Derivatives (local diets) & Preparation Techniques \\
\hline \multirow[t]{2}{*}{ Cassava } & Garri & $\begin{array}{l}\text { Peel the cassava, wash and grind and put in a sack for a day. Apply pressure by placing a jack on the sack } \\
\text { for } 3 \text { days to remove moisture. Then fry in an empty pan for 30-40 mins to produce coarse grained roasted } \\
\text { flour. }\end{array}$ \\
\hline & Amala & $\begin{array}{l}\text { Peel the cassava, wash and soak in warm water for 3-5 days. Remove from the water and dry in the sun. } \\
\text { Grind to become cassava flour (lafun). Then cook with boiled water. }\end{array}$ \\
\hline \multirow[t]{2}{*}{ Yam } & Isu sisun & Make a charcoal fire, put raw yam on it to roast. Scrap off the burnt peel. \\
\hline & Iyan & Peel the yam, cook with water and pound with mortar and pestle. \\
\hline Plantain & Boli & $\begin{array}{l}\text { Roasted plantain: Remove the peel or skin. Put on charcoal fire to roast, turn several times to avoid burn- } \\
\text { ing. Scrap off the burnt part. }\end{array}$ \\
\hline \multirow[t]{2}{*}{ Maize } & Agbado sisun & Remove the corn husk. Put on charcoal fire to roast. \\
\hline & Langbe & Remove the corn husk. Put into a pot of water. Cook with water for 40 minutes. \\
\hline
\end{tabular}

food, the diets were prepared by the local women in the study areas. The prepared diets, the raw food crop and soil samples from the raw food stuffs were transported to the laboratory where they were oven dried at a temperature of $100^{\circ} \mathrm{C}$ to attain a constant weight. At the laboratory, samples after drying were crushed, homogenized and sieved to pass through $2 \mathrm{~mm}$ mesh size. They were transferred into uncontaminated empty cylindrical plastic containers of uniform size $(60 \mathrm{~mm}$ height by $65 \mathrm{~mm}$ diameter) and were sealed for a period of 4 weeks. This was done in order to allow for Radon and its short-lived progenies to reach secular radioactive equilibrium prior to gamma spectroscopy.

\subsection{Radioactivity Measurements in the Samples}

\subsubsection{Radioactivity Counting}

Radioactivity counting in this work was carried out using a lead-shielded $76 \mathrm{~mm} \times 76 \mathrm{~mm} \mathrm{NaI}(\mathrm{TI})$ detector crystal (Model No. 802 series, Canberra Inc.) coupled to a Canberra Series 10 plus Multichannel Analyzer (MCA) (Model No. 1104) through a preamplifier. The detector has a resolution of about $8 \%$ at $0.662 \mathrm{MeV}$ of ${ }^{137} \mathrm{Cs}$. This is capable of distinguishing the gamma ray energies considered during these measurements. The Uranium -238 and Thorium -232 activities were determined indirectly through the activities of their daughter products. The choice of the reference nuclides for their activity determination was made based on the fact that NaI(Tl) detector used in this study has a poor resolution, hence, the peaks of interest to be considered would be sufficiently discriminated and intense. Based on this consideration, therefore, the ${ }^{226} \mathrm{Ra}$ content of the samples was determined from the intensity of the $1.760 \mathrm{MeV} \gamma$-ray peak from ${ }^{214} \mathrm{Bi}$, the ${ }^{232} \mathrm{Th}$ content from the $2.615 \mathrm{MeV} \gamma$-ray peak from ${ }^{208} \mathrm{Tl}$ and the ${ }^{40} \mathrm{~K}$ content from $1.460 \mathrm{MeV}$ $\gamma$-ray peak following the decay of ${ }^{40} \mathrm{~K}$. These peaks are clean, reasonably strongly with very low continuum. Caesium-137 ( $\sim 30$ yr) is a very common fallout radionuclide whose presence is usually an index of environmental pollution due to nuclear accidents and weapon tests. As a check for the presence of this radionuclide, an indication for any radioactive contamination in the environment following past mining activities in the area, a fourth region of interest was created around $0.662 \mathrm{MeV}$ $\gamma$-ray peak. Its presence in the environment is inimical to public health as it accumulates in many types of tissues and its penetrating $\gamma$-ray reaches all body cells [8].

The samples of both soil and food were placed symmetrically on top of the detector and counting for each sample was done for a period of $10 \mathrm{hr}(36,000 \mathrm{~s})$. The net area count under the photopeaks of each of the radionuclide was computed from the memory of the MCA using the firmware algorithm which subtracts counts due to Compton scattering of higher peaks and other background effects from the total area.

\subsubsection{Radioactivity Determination}

The net area count after background corrections in each photopeak was used in the computation of the activity concentration of each of the radionuclides in the food and soil samples. The activity concentrations in the samples were obtained using the expression [9-11]:

$$
C\left(\mathrm{~Bq} \cdot \mathrm{kg}^{-1}\right)=\frac{C_{n}}{\varepsilon P_{\gamma} M_{s}}
$$

where $C$ is the activity concentration of the radionuclide in the sample, $C_{n}$ is the count rate under each photopeak due to each radionuclides, $\varepsilon$ is the detector efficiency of 
the specific $\gamma$-ray, $P_{\gamma}$ is the absolute transition probability of the specific $\gamma$-ray and $M_{s}$ is the mass of the sample $(\mathrm{kg})$. Equation (1) has been shown to be expressed as [12, 13]:

$$
C\left(\mathrm{~Bq} \cdot \mathrm{kg}^{-1}\right)=\frac{C_{K}}{A_{K}} \cdot A
$$

$C_{k}$ is the activity concentration of the radionuclide in the standard reference sample $\left(\mathrm{Bq} \cdot \mathrm{kg}^{-1}\right), A$ is the net area count after background correction in the spectrum of the radionuclide in the sample and $A_{K}$ is the net area count after background correction under the spectrum of the radionuclide in the standard reference sample. The standard reference soil sample used was prepared from Rocketdyne Laboratories California; USA which is traceable to a mixed standard gamma source (Ref. No. 48722-356) by Analytic Inc. Atlanta, Georgia. For the food samples the reference standard sample was obtained from International Atomic Energy Agency traceable to source Ref No. IAEA-312.

\section{Results and Discussion}

\subsection{Activity Concentration in the Food Samples}

Using Equations (1) and (2), the activity concentration in the farm soil samples, food crops and their diet derivatives were determined. The activity concentration of the ${ }^{40} \mathrm{~K},{ }^{226} \mathrm{Ra}$ and ${ }^{232} \mathrm{Th}$ in the soil samples from the farms where the food crop samples were collected are presented in Table 2. The activity concentrations of the radionuclides in the different food crops and their local food derivatives are presented in Table $\mathbf{3}$ for Cassava, Table 4 for Yam, Tables 5 and $\mathbf{6}$ for Plantain and Maize respectively.

As could be seen from the Tables $\mathbf{3}$ to $\mathbf{6}$ food preparation techniques were repeated thrice on each food crops for the diet derivable from each of them. Each experiment was carried out for each food crops obtained from different farms in order to determine the consistency of variations in addition or reduction of activity concentrations of the radionuclides for each preparation techniques.

Table 2. Activity concentrations of the radionuclides, absorbed dose rates and annual effective dose rates due to the farm soils from where the raw food crops were collected.

\begin{tabular}{ccccccc}
\hline Food Samples & Farm soil samples & ${ }^{40} \mathrm{~K}\left(\mathrm{~Bq} \cdot \mathrm{kg}^{-1}\right)$ & ${ }^{226} \mathrm{Ra}\left(\mathrm{Bq} \cdot \mathrm{kg}^{-1}\right)$ & ${ }^{232} \mathrm{Th}\left(\mathrm{Bq} \cdot \mathrm{kg}^{-1}\right)$ & Absorbed Dose $(\mathrm{nGy} / \mathrm{h})$ & Effective dose $\left(\mu \mathrm{Sv} \cdot \mathrm{y}^{-1}\right)$ \\
\hline Cassava & 1 & $527.29 \pm 46.56$ & $6.40 \pm 2.03$ & $6.54 \pm 0.30$ & 29.05 & 0.02 \\
& 2 & $550.78 \pm 48.60$ & $5.86 \pm 1.51$ & $7.01 \pm 0.63$ & 30.07 & 0.02 \\
\multirow{2}{*}{ Yam } & 3 & $326.08 \pm 29.10$ & $3.13 \pm 1.04$ & $5.01 \pm 0.23$ & 18.17 & 0.01 \\
& 1 & $583.07 \pm 51.41$ & $4.88 \pm 0.28$ & $4.05 \pm 0.76$ & 29.19 & 0.02 \\
\multirow{2}{*}{ Plantain } & 2 & $428.60 \pm 29.29$ & $6.25 \pm 0.34$ & $4.43 \pm 0.51$ & 23.56 & 0.01 \\
& 3 & $336.96 \pm 30.03$ & $\mathrm{ND}$ & $8.35 \pm 0.95$ & 19.20 & 0.01 \\
& 1 & $836.08 \pm 73.49$ & $5.55 \pm 0.31$ & $5.87 \pm 0.85$ & 31.22 & 0.02 \\
Maize & 2 & $257.25 \pm 23.16$ & $5.35 \pm 1.46$ & $7.42 \pm 1.92$ & 17.76 & 0.01 \\
\end{tabular}

Table 3. Activity concentrations of the radionuclides in cassava (Manihot esculenta) and local diet derivatives and the annual effective dose due to ingestions.

\begin{tabular}{|c|c|c|c|c|c|}
\hline Expt & Food Samples/Diet Derivatives & ${ }^{40} \mathrm{~K}\left(\mathrm{~Bq} \cdot \mathrm{kg}^{-1}\right)$ & ${ }^{226} \mathrm{Ra}\left(\mathrm{Bq} \cdot \mathrm{kg}^{-1}\right)$ & ${ }^{232} \mathrm{Th}\left(\mathrm{Bq} \cdot \mathrm{kg}^{-1}\right)$ & Effective Dose $\left(\mu \mathrm{Sv} \cdot \mathrm{y}^{-1}\right)$ \\
\hline \multirow{4}{*}{1} & Raw Cassava & $452.23 \pm 40.02$ & ND & ND & 0.03 \\
\hline & Garri & $506.77 \pm 44.73$ & $4.09 \pm 1.17$ & ND & 0.04 \\
\hline & Amala & $463.64 \pm 40.99$ & $2.94 \pm 0.06$ & $8.19 \pm 1.78$ & 0.05 \\
\hline & Lafun & $484.83 \pm 42.83$ & $4.94 \pm 0.28$ & ND & 0.04 \\
\hline \multirow{8}{*}{2} & Raw Cassava & $534.01 \pm 47.10$ & $8.03 \pm 0.42$ & ND & 0.04 \\
\hline & Garri & $441.57 \pm 39.07$ & $12.05 \pm 2.70$ & $3.58 \pm 0.41$ & 0.05 \\
\hline & Amala & $379.86 \pm 33.73$ & $6.26 \pm 1.84$ & $0.21 \pm 0.02$ & 0.03 \\
\hline & Lafun & $431.44 \pm 38.19$ & $8.16 \pm 0.43$ & $6.64 \pm 0.76$ & 0.05 \\
\hline & Raw Cassava & $479.87 \pm 42.42$ & $2.97 \pm 1.02$ & $0.67 \pm 0.08$ & 0.04 \\
\hline & Garri & $424.76 \pm 37.61$ & $5.12 \pm 0.28$ & $3.86 \pm 0.45$ & 0.04 \\
\hline & Amala & $370.31 \pm 32.91$ & $10.64 \pm 2.99$ & ND & 0.04 \\
\hline & Lafun & $429.23 \pm 38.00$ & $11.64 \pm 1.73$ & ND & 0.04 \\
\hline
\end{tabular}

Local names: Raw cassava_Fried cassava paste_ Gari; Boiled cassava flour_Amala; Dried cassava flour—lafun. 
Table 4. Activity concentrations of the radionuclide in yam (Dioscorea sp) and diet derivatives and the annual effective dose due to ingestions.

\begin{tabular}{cccccc}
\hline Expt. & Food Samples & ${ }^{40} \mathrm{~K}\left(\mathrm{~Bq} \cdot \mathrm{kg}^{-1}\right)$ & ${ }^{226} \mathrm{Ra}\left(\mathrm{Bq} \cdot \mathrm{kg}^{-1}\right)$ & ${ }^{232} \mathrm{Th}\left(\mathrm{Bq} \cdot \mathrm{kg}^{-1}\right)$ & Effective Dose $\left(\mu \mathrm{Sv} \cdot \mathrm{y}^{-1}\right)$ \\
\hline \multirow{2}{*}{1} & Raw yam & $459.04 \pm 40.6$ & $7.23 \pm 2.88$ & $2.66 \pm 0.31$ & 0.03 \\
& Roasted yam & $491.64 \pm 43.44$ & $3.07 \pm 0.18$ & ND & 0.02 \\
& Boiled yam & $473.24 \pm 41.84$ & $0.15 \pm 0.01$ & $\mathrm{ND}$ & 0.02 \\
2 & Raw yam & $481.42 \pm 42.55$ & $1.27 \pm 0.08$ & $\mathrm{ND}$ & 0.02 \\
& Roasted yam & $504.07 \pm 44.52$ & $5.87 \pm 0.32$ & $\mathrm{ND}$ & 0.03 \\
& Boiled yam & $426.49 \pm 37.55$ & $7.04 \pm 0.37$ & $\mathrm{ND}$ & 0.02 \\
3 & Raw yam & $490.67 \pm 43.35$ & $9.60 \pm 0.49$ & $\mathrm{ND}$ & 0.03 \\
& Roasted yam & $585.81 \pm 51.61$ & $4.64 \pm 0.26$ & $\mathrm{ND}$ & 0.03 \\
\end{tabular}

Local names: Raw Yam-Isu; Roasted Yam-Isu sisun; Boiled yam-Isu sise.

Table 5. Activity concentrations of the radionuclide in plantain (Plantago sp) and diet derivatives and the annual effective dose due to ingestions.

\begin{tabular}{|c|c|c|c|c|c|}
\hline Expt. & Food Samples & ${ }^{40} \mathrm{~K}\left(\mathrm{~Bq} \cdot \mathrm{kg}^{-1}\right)$ & ${ }^{226} \mathrm{Ra}\left(\mathrm{Bq} \cdot \mathrm{kg}^{-1}\right)$ & ${ }^{232} \mathrm{Th}\left(\mathrm{Bq} \cdot \mathrm{kg}^{-1}\right)$ & Effective Dose $\left(\mu \mathrm{Sv} \cdot \mathrm{y}^{-1}\right)$ \\
\hline \multirow{3}{*}{1} & Raw Plantain & $424.76 \pm 37.64$ & $3.13 \pm 0.19$ & ND & 0.44 \\
\hline & Roasted Plantain & $470.98 \pm 41.65$ & $8.54 \pm 1.40$ & ND & 0.53 \\
\hline & Boiled Plantain & $503.18 \pm 44.43$ & $7.63 \pm 0.30$ & $0.99 \pm 0.12$ & 0.54 \\
\hline \multirow{3}{*}{2} & Raw Plantain & $410.83 \pm 36.43$ & $4.60 \pm 2.03$ & $4.81 \pm 0.56$ & 0.62 \\
\hline & Roasted Plantain & $376.68 \pm 33.47$ & $6.57 \pm 1.86$ & $2.89 \pm 0.34$ & 0.53 \\
\hline & Boiled Plantain & $423.83 \pm 37.55$ & $7.04 \pm 0.37$ & ND & 0.47 \\
\hline \multirow{3}{*}{3} & Raw Plantain & $472.58 \pm 41.78$ & $2.75 \pm 0.16$ & ND & 0.48 \\
\hline & Roasted Plantain & $417.51 \pm 37.00$ & $9.66 \pm 0.49$ & $1.94 \pm 0.23$ & 0.56 \\
\hline & Boiled Plantain & $486.64 \pm 43.01$ & $7.93 \pm 2.07$ & ND & 0.47 \\
\hline
\end{tabular}

Local names: Raw Plantain-Ogede; Roasted Plantain—Boli; Boiled Plantain_-Ogede sise.

Table 6. Activity concentrations of the radionuclide in raw maize (Zea mays) and diet derivatives and the annual effective dose due to ingestions.

\begin{tabular}{|c|c|c|c|c|c|}
\hline Expt. & Food type/Diet Derivative & ${ }^{40} \mathrm{~K}\left(\mathrm{~Bq} \cdot \mathrm{kg}^{-1}\right)$ & ${ }^{226} \mathrm{Ra}\left(\mathrm{Bq} \cdot \mathrm{kg}^{-1}\right)$ & ${ }^{232} \mathrm{Th}\left(\mathrm{Bq} \cdot \mathrm{kg}^{-1}\right)$ & Effective Dose $\left(\mu \mathrm{Sv} \cdot \mathrm{y}^{-1}\right)$ \\
\hline 1 & Raw maize (Agbado) & $386.28 \pm 34.28$ & $1.76 \pm 0.68$ & $6.55 \pm 0.74$ & 0.70 \\
\hline 3 & Boiled maize (Langbe) & $403.00 \pm 5.73$ & $5.26 \pm 0.29$ & ND & 0.59 \\
\hline
\end{tabular}

Addition or reduction of radionuclides in the derivable composite diets could be observed from the tables. It represents the radionuclide concentrations value in the diets with respect to the raw concentration value. As could be seen from Tables $3-6,{ }^{40} \mathrm{~K}$ showed more radionuclide addition in the diet derivatives than reduction. Potassium-40 is usually of limited interest because, as an isotope of an essential element, it is homeostatically controlled in the human cells. As a result, the body content of ${ }^{40} \mathrm{~K}$ is determined largely by its physiological characteristics rather than by its intake. Of particular radiological interest is ${ }^{226} \mathrm{Ra}$ and ${ }^{232} \mathrm{Th}$ concentrations in the diets. It has been estimated that a large portion of at least oneeighth of the mean annual effective dose due to natural sources can be attributed to the intake of food. The ra- dionuclides in the naturally occurring ${ }^{238} \mathrm{U}$ and ${ }^{232} \mathrm{Th}$ series contribute about $30 \%$ to $60 \%$ to the internal radiation dose $[11,14]$. From the tables it is clearly evident that there is radionuclide addition of ${ }^{226} \mathrm{Ra}$ in all the diet derivatives from the crops under consideration while reduction was observed for ${ }^{232} \mathrm{Th}$ except in cassava. The preparation techniques of exposing some of the cassava diet processing to the sun for drying may introduce soil or other debris into the food items hence influencing the radioactivity. Thorium-232 because of its low solubility, it does not biomagnify in terrestrial or aquatic food chains while ${ }^{226} \mathrm{Ra}$ solubility may therefore account for its concentrations in the raw food crops as well as in the diets. It could also be observed that the same preparation technique does not translate to the same amount of ra- 
dionuclide addition or reduction in the diets.

\subsection{Absorbed Dose Rates and Annual Effective Dose in Soil Samples}

\section{Absorbed Dose Rates}

The absorbed dose rate, $D\left(\mathrm{nGy} \cdot \mathrm{h}^{-1}\right)$ in air at $1 \mathrm{~m}$ above the ground level for soils containing the concentrations of the radionuclides measured in the samples is calculated using the equation [14]:

$$
D=a \cdot C_{\mathrm{Ra}}+b \cdot C_{\mathrm{Th}}+c \cdot C_{\mathrm{K}}+d \cdot C_{\mathrm{Cs}}
$$

where a is the dose rate per unit ${ }^{226} \mathrm{Ra}$ activity concentration $\left(4.27 \times 10^{-10} \mathrm{~Gy} \cdot \mathrm{h}^{-1} / \mathrm{Bq} \cdot \mathrm{kg}^{-1}\right), C_{\mathrm{Ra}}$ is the concentration of ${ }^{226} \mathrm{Ra}$ in the sample $\left(\mathrm{Bq} \cdot \mathrm{kg}^{-1}\right), b$ is the dose rate per unit ${ }^{232} \mathrm{Th}$ activity concentration $\left(6.62 \times 10^{-10} \mathrm{~Gy} \cdot \mathrm{h}^{-1} /\right.$ $\left.\mathrm{Bq} \cdot \mathrm{kg}^{-1}\right), C_{\mathrm{Th}}$ is the concentration of ${ }^{228} \mathrm{Th}$ in the sample $\left(\mathrm{Bq} \cdot \mathrm{kg}^{-1}\right), c$ is the dose rate per unit ${ }^{40} \mathrm{~K}$ activity concentration $\left(0.43 \times 10^{-10} \mathrm{~Gy} \cdot \mathrm{h}^{-1} / \mathrm{Bq} \cdot \mathrm{kg}^{-1}\right), C_{\mathrm{K}}$ is the concentration of ${ }^{40} \mathrm{~K}$ in the sample $\left(\mathrm{Bq} \cdot \mathrm{kg}^{-1}\right), d$ is the dose rate per unit ${ }^{137} \mathrm{Cs}$ activity concentration $\left(0.30 \times 10^{-10} \mathrm{~Gy} \cdot \mathrm{h}^{-1} /\right.$ $\left.\mathrm{Bq} \cdot \mathrm{kg}^{-1}\right)$ and $C_{\mathrm{Cs}}$ is the concentration of ${ }^{137} \mathrm{Cs}$ in the sample $\left(\mathrm{Bq} \cdot \mathrm{kg}^{-1}\right)$. Since Cesium-137 was not detected in any of the samples, the last term in Equation (4) was taken as zero. The absorbed $\gamma$-dose rates in air are usually related to human absorbed $\gamma$-dose in order to assess radiological implications. In assessing the outdoor effective dose equivalent to members of the population, two important factors were considered. The first is a factor that converts the absorbed dose rates $\left(\mathrm{Gy} \cdot \mathrm{h}^{-1}\right)$ in air to human outdoor effective dose rates $\left(\mathrm{Sv} \cdot \mathrm{y}^{-1}\right)$ while the second factor gives the proportion of the total time for which the typical individual is exposed to outdoor or indoor radiation. The United Nations Scientific Committee on the effects of Atomic Radiation [14] has recommended $0.7 \mathrm{~Sv} \cdot \mathrm{Gy}^{-1}$ as the value of the first factor and 0.2 and 0.8 as for outdoor and indoor occupancy factors, respectively. This second factor implies that the average individual spends only 4.8 hours (about 5 hours per day) outdoors. In this work, only outdoor exposure from $\gamma$-rays sources due to the concentrations of the primordial radionuclides in the soil were considered. The effective dose rate resulting from the absorbed dose rate values was calculated using the following relation:

$$
E_{\text {air }}=T f Q D_{\text {air }} \varepsilon
$$

where $E_{\text {air }}$ is the effective dose rate $\left(\mu \mathrm{Sv} \cdot \mathrm{y}^{-1}\right), T$ is time being $8766 \mathrm{~h} \cdot \mathrm{y}^{-1}, \mathrm{f}$ is the outdoor occupancy factor that corrects for the average time spent outdoors (0.2), $Q$ is the quotient of the effective dose rate and absorbed dose rate in air $\left(0.7 \mathrm{~Sv} \cdot \mathrm{Gy}^{-1}\right), \varepsilon$ is a factor converting nano $\left(10^{-9}\right)$ into micro $\left(10^{-6}\right)$ and $D_{\text {air }}$ is the absorbed dose rate in air $\left(\mathrm{nGy} \cdot \mathrm{h}^{-1}\right)$. The results of the gamma absorbed dose rates and the corresponding annual outdoor effective doses due to the farm soils are also presented in Table 2.
These values were within the normal ranges in the world [14]. These value deviate a little from the anticipated high levels in the soil indicated in previous studies $[1,4]$. The reason may be attributed to the fact the villages and farmlands considered in the study are located in the remote areas which were far from industrial activities in the town of Abeokuta and its characteristic outcrop of granite rocks known for high concentrations of natural radionuclides. This is reflected on the concentrations of the radionuclide in the food crops and the soil.

\subsection{Ingestion Effective Dose Evaluation}

Radiation doses obtained due to the intake of food is calculated from the amount of radionuclide deposited on foodstuff, the activity concentration of particular radionuclide in food per unit deposition, the consumption rate of the food products and the dose per unit activity ingested. To summarize, the effective dose $H$ to a certain tissue $T$ due to intake of radionuclide $r$ is given by [15]:

$$
H_{T, r}=\sum\left(U^{i} \times C_{r}^{i}\right) \times g_{T, r}
$$

where, $i$ denotes a food group, the coefficients $U^{i}$ and $C_{r}^{i}$ denote the consumption rate $\left(\mathrm{kg} \cdot \mathrm{y}^{-1}\right)$ and activity concentration of the radionuclide $r$ of interest $\left(\mathrm{Bq} \cdot \mathrm{kg}^{-1}\right)$, respectively, and $g_{T, r}$ is the dose conversion coefficient for ingestion of radionuclide $r\left(\mathrm{~Sv} \cdot \mathrm{Bq}^{-1}\right)$ in tissue $T$. For adult members of the public, the recommended dose conversion coefficient $g_{T, r}$ for ${ }^{40} \mathrm{~K},{ }^{226} \mathrm{Ra},{ }^{228} \mathrm{Th}$, and ${ }^{137} \mathrm{Cs}$, are $6.2 \times 10^{-9} \mathrm{~Sv} \cdot \mathrm{Bq}^{-1}, 2.8 \times 10^{-7} \mathrm{~Sv} \cdot \mathrm{Bq}^{-1}, 7.2 \times 10^{-8}$ $\mathrm{Sv} \cdot \mathrm{Bq}^{-1}$, and $1.3 \times 10^{-8} \mathrm{~Sv} \cdot \mathrm{Bq}^{-1}$, respectively [16]. Presently, no site specific consumption data exist in the study area and as such we have adopted the country's mean annual consumption rate per capita values (Table 7) to enable us calculate the effective dose due intake of the food stuffs using Equation (6).

The results are presented in column 6 of Tables 3-6 for each of the crops and the diet derivatives. As could be observed from these tables, for the tuberous food crop samples, the annual effective ingestion doses in the raw and different composite diets were $0.02-0.04 \mu \mathrm{Sv}$ and cumulatively $0.04-0.05 \mu \mathrm{Sv}$ while in the non-tuberous crops the doses were $0.44-0.70 \mu \mathrm{Sv}$ and cumulatively greater than $1 \mu \mathrm{Sv}$ respectively.

Table 7. Consumption rate for different food products.

\begin{tabular}{cc}
\hline Food stuffs & Consumption rate $\left(\mathbf{k g} \cdot \mathbf{y r}^{\mathbf{- 1}}\right)$ \\
\hline Cassava & 116.6 \\
Yam & 76 \\
Plantain & 16.539 \\
Maize & 20.7 \\
\hline
\end{tabular}

Source: Food Balance Sheet, Nigeria. 2002. 
The coefficient of variation (reduction or addition) in the ingestion effective dose due to diet preparation technique could be determined using the Equation (7) below:

$$
K_{i, f}=\frac{D_{T_{R i, f}}-D_{T_{D i, f}}}{D_{T_{R i, f}}}
$$

where $K_{i, f}$ is the coefficient of ingestion dose variation in the food crop $i$ for diet type technique $f, D_{T_{R i f}}$ is the total ingestion dose in the raw food crop $i$, and $D_{T_{D i, f}}$ is the total ingestion dose in the diet type of food crop $i$ due to preparation technique $f$. If $K>0$ it implies ingestion dose reduction due to preparation technique type $f$ for food type $i$, while $K<0$ denotes addition of dose due to ingestion of diet type of food crop $i$ due to preparation technique type $f$. As could be seen from the tables most of the crops and diet preparation techniques showed that $K>0$ most especially from ${ }^{226} \mathrm{Ra}$.

\section{Conclusion}

The activity concentrations in farm soils and major food crops of dietary importance to the population in Abeokuta and their diet derivatives have been determined via gamma-ray spectroscopy. Tuberous food crops and their diet derivatives resulting from different preparation techniques showed lower population ingestion dose than the non tuberous crops where ingestion doses were greater than $1 \mu \mathrm{Sv} \cdot \mathrm{y}^{-1}$. The radionuclide addition or reduction due to food preparation technique was investigated and results indicate that radionuclide addition was evident in the diets than in the raw food crops. It could also be observed that the same repeated preparation technique does not translate to the same amount of radionuclide addition or reduction in the diets. Results also showed that there is more ingestion dose to the population resulting from addition of ${ }^{226} \mathrm{Ra}$ in diets due to different preparation techniques than from ${ }^{40} \mathrm{~K}$ and ${ }^{232} \mathrm{Th}$.

\section{Acknowledgements}

The authors wish to thank the International Foundation for Science (IFS) Stockholm, Sweden, for providing the research grant (E-3585-2) used in carrying out this study under her Food Science Programme.

\section{REFERENCES}

[1] I. P. Farai and N. N. Jibiri, "Baseline Studies of Terrestrial Outdoor Gamma Dose Rate Levels in Nigeria," $R a$ diation Protection Dosimetry, 2000, Vol. 88, No. 3, pp. 247-254. doi:10.1093/oxfordjournals.rpd.a033042

[2] N. N. Jibiri and O. S. Bankole, "Soil Radioactivity and Radiation Absorbed Dose Rates at Roadsides in HighTraffic Density Area in Ibadan Metropolis, Southwestern, Nigeria," Radiation Protection Dosimetry, Vol. 118, No. 4, 2006, pp. 453-458.
[3] N. N. Jibiri, "Assessment of Health Risk Associated with Terrestrial Gamma Radiation Dose Rate Levels in Nigeria," Environment International, Vol. 27, No. 1, 2001, pp. 21-26. doi:10.1016/S0160-4120(01)00039-3

[4] I. P. Farai and U. E. Vincent, "Outdoor Radiation Level Measurement in Abeokuta, Nigeria by Thermoluminiscent Dosimetry," Nigerian Journal of Physics, Vol. 18, 2006, pp. 121-126.

[5] O. Fasunwon, J. Olowofela, O. Akinyemi, B. Fasunwon and O. Akintokun, "Contaminants Evaluation as Water Quality Indicators in Ago-Iwoye, Southwestern Nigeria," African Physical Review, Vol. 2, No. 1, 2008, pp. 10-116.

[6] A. O. Awodugba and P. Tchokossa, "Assessment of Radionuclide Concentrations in Water Supply from BoreHoles in Ogbomoso land, Western Nigeria," Indoor and Built Environment, Vol. 17, No. 2, 2008, pp. 183-186. doi:10.1177/1420326X08089551

[7] O. S. Ajayi and J. Achuka, "Radioactivity in Drilled and Dug Well Drinking Water of Ogun State, Southwestern Nigeria and Consequent Dose Estimates," Radiation Protection Dosimetry, Vol. 135, No. 1, 2009, pp. 54-63. doi:10.1093/rpd/ncp095

[8] R. A. Sutherland and E. de Jong, "Statistical Analysis of Gamma-Emitting Radionuclide Concentrations for Three Fields in Southern Saskatchewan, Canada," Health Physics, Vol. 58, No. 4, 1990, pp. 417-428. doi:10.1097/00004032-199004000-00004

[9] M. K. Akinloye and J. B. Olomo, "The Measurement of the Natural Radioactivity in Some Tubers Cultivated in Farmlands within the Obafemi Awolowo University IleIfe, Nigeria," Nigerian Journal of Physics, Vol. 12, 2000, pp. 60-63.

[10] I. P. Farai and J. A. Ademola, "Population Dose Due to Building Materials in Ibadan, Nigeria," Radiation Protection Dosimetry, Vol. 95, No. 1, 2001, pp. 69-73. doi:10.1093/oxfordjournals.rpd.a006527

[11] N. N. Jibiri, I. P. Farai and S. K. Alausa, "Activity Concentration of ${ }^{226} \mathrm{Ra},{ }^{228} \mathrm{Th}$ and ${ }^{40} \mathrm{~K}$ in Different Food Crops from a High Background Radiation Area in Bitsichi, Jos Plateau Nigeria," Radiation and Environmental Biophysics, Vol. 46, No. 1, 2007, pp. 53-59. doi:10.1007/s00411-006-0085-9

[12] N. N. Jibiri and A. O. Ajao, "Natural Activities of ${ }^{40} \mathrm{~K}$, ${ }^{238} \mathrm{U}$ and ${ }^{232} \mathrm{Th}$ in Elephant Grass (Pennisetum purpureum) in Ibadan Metropolis, Nigeria," Journal of Environmental Radioactivity, Vol. 78, No. 1, 2005, pp. 105-111. doi:10.1016/j.jenvrad.2004.02.007

[13] N. N. Jibiri, I. P. Farai and S. K. Alausa, "Estimation of Annual Effective Dose Due to Natural Radioactive Elements in Ingestion of Foodstuff in Tin Mining Area of Jos-Plateau, Nigeria," Journal of Environmntal Radioactivity, Vol. 94, No. 1, 2007, pp. 31-40. doi:10.1016/j.jenvrad.2006.12.011

[14] UNSCEAR, "Sources, Effects and Risks of Ionizing Radiation," Report to the General Assembly, United Nations Committee on the Effects of Atomic Radiation, New York, 2000.

[15] International Commission on Radiological Protection (ICRP), “Age-Dependent Doses to Members of the Public 
from Intake of Radionuclides: Part 5 Compilations of Ingestion and Inhalation Dose Coefficients (ICRP Publication 72)," Pergamon Press, Oxford, 1996.

[16] International Commission on Radiological Protection
(ICRRP), "Protection of the Public in Situations of Prolonged Radiation Exposure (ICRP Publication 82)," Pergamon Press, Oxford, 2000. 